\title{
Assessing Teacher and Librarian Collaboration: A Preliminary Report
}

\author{
Patricia Montiel-Overall \\ Assistant Professor \\ The University of Arizona \\ U.S.A.
}

\begin{abstract}
Exploratory factor analysis was used to examine the structure of a 32-item teacher and librarian collaboration survey (TLC-II). The survey consisted of two scales with 16 items in each scale, Frequency and Importance to Student Learning. Scores from teacher surveys $(N=194)$ were examined using principal axis factoring and oblique rotation to identify underlying constructs. A four factor interpretable structure of teacher and librarian collaboration emerged providing support for a proposed model of teacher and librarian collaboration. Internal consistency was high for the overall scale and for each of the factors. The results of this study provide a basis for further refinement of the instrument in preparation for broad distribution among teachers and librarians.
\end{abstract}

Collaboration, teacher and librarian collaboration, factor analysis

\section{Introduction}

Collaboration among teachers and librarians ${ }^{1}$ is recommended in professional guidelines as an integral part of school librarianship (American Association of School Librarians [AASL] and Association for Educational Communications and Technology [AECT], 1998). An early study by Lance (1993) commonly referred to as "the Colorado Study" found indications that higher standardized test results occurred in schools where teachers worked with librarians. These results have also been found in additional studies across the United States leading to efforts to increase teacher and librarian collaboration as a means of improving student academic achievement (Lance, 1994, 2001, 2002; Lance et al., 1993, 1999, 2000, 2001, 2005; Lance \& Russell, 2004; Rodney et al., 2002, 2003).

Considerable anecdotal evidence of the positive effect of teacher and librarian collaboration on improved student academic achievement also exists. For example, librarians have written extensively about the importance of teacher and librarian collaboration in schools to meet standards for students to be successful (Bush, 1998; Busseo, 2003; Jinkins, 2001; Milbury, 2005), and about the attributes needed for librarians to be successful collaborators (Abilock, 2002). However, the types of practices undertaken by teachers and librarians are not always clearly understood. Such information is essential to further understand the relationship between teacher and librarian collaboration and improved student academic achievement. The purpose of this paper is to discuss preliminary results from a study assessing the types of

\footnotetext{
${ }^{1}$ The term librarian is used throughout to avoid confusion in the discussion of teacher and librarian collaboration. Other preferred terms include teacher-librarian, school library media specialist, information specialist, and media specialist.
} 
collaborative practices that teachers and librarians engage in and examining factors that may contribute to teacher and librarian collaboration.

\section{Background}

Although teacher and librarian collaboration is a relatively new phenomenon for school librarians (AASL \& AECT, 1998), the notion of librarians working closely with teachers to plan and implement instruction (as opposed to gathering information and distributing it) has been discussed within the profession for over twenty years (Loertscher, 1982, 1988). Efforts to expand the role of librarians into curriculum planning and implementation were proposed, and suggestions that librarians become co-planners, coimplementors, and co-evaluators with teachers were widely discussed in the literature (Callison, 1997) before being recommended in professional guidelines for school librarians (AASL and AECT, 1998). Building on the works of others in the field of school librarianship, Montiel-Overall (2005) proposed a model of teacher and librarian collaboration (TLC Model), and identified possible facets of collaboration (Montiel-Overall, 2006) between teachers and librarian ranging from low- to high-end collaboration along a continuum of collaborative practices. A preliminary survey of teacher and librarian collaboration (TLC-Survey) found some support for the proposed model. Using exploratory factor analysis, two factors emerged, Integrated Instruction and Traditional Role for Teacher and Librarian, from an instrument distributed to teachers and librarians. Utilizing these results, an expanded measure of teacher and librarian collaborative practices was developed. This paper reports on results from a pilot study of a second teacher and librarian collaboration survey (TLC-II). The instrument was developed to examine teacher and librarian collaborative practices and to test the proposed TLC Model, which identified four facets of collaborative practices that emerged from a broad review of the literature (Callison, 1997; Lance, 1994, 2001, 2002; Lance, et al., 1993, 1999, 2000, 2001, 2005; Lance \& Russell, 2004; Loertscher, 1982, 1988, 2000; Rodney, et al., 2002, 2003). The facets (originally called "Models") reflected the range of practices discussed in the literature. For example, Facet A: Coordination identified practices that were commonly carried out between teachers and librarians such as organizational or scheduling responsibilities. Facet B: Cooperation involved traditional librarian practices in which teachers and librarians worked together. These included such activities as finding resources for teachers to use in instruction and helping teachers by giving booktalks. Facet C: Integrated Instruction reflected practices recommended by professional guidelines. These practices included jointly planned and taught lessons. Finally, Facet D: Integrated Curriculum described broad application across a school or school district of teachers and librarians working together to integrate instruction (i.e. jointly planned lessons described in Facet C: Integrated Instruction would occur across a school or school district).

\section{Method}

\section{Description of Sample}

Data were collected from 204 participating teachers and librarians from 11 elementary schools in a metropolitan school district in the southwest United States. Because of the small number of librarians in the study, only surveys from 194 teacher surveys were analyzed. Of these, the majority were female (86\%), reflecting the population of the teaching profession. Teachers breakdown by age was $33 \%$ between $20-30$ years of age, $24 \%(n=48)$ between 31 - 
40 years of age, $24 \%(n=48)$ between $41-50$ years of age, $29 \%(n=57)$ between the ages of $51-60$, and $3 \%(n=7)$ reported being over the age of 61 . One teacher did not respond to this question. The ethnicity breakdown for teachers in the sample was $49 \%(n=95)$ identified as White (non-Hispanic), 44\% $(n=87)$ identified as Hispanic/Latino, 2\% $(n=4)$ identified as Asian-American, $1 \%(n=3)$ identified as African-American, and 1\% $(n=3)$ identified as Other. Two teachers did not respond to this question. Educational level was reported by 191 teachers. Of these, 55\% $(n=106)$ had a Bachelor's degree, 39\% $(n=76)$ had a Master's degree, $1 \%(n=2)$ of teachers reported having a Masters of Library Science, and 37\% $(n=7)$ reported Other. For teaching experience, $28 \%(n=56)$ teachers reported having taught for less than 6 years, 20\% $(n=66)$ had between 6-10 years, 13\% $(n=27)$ had between $11-15$ years, $22 \%(n=43)$ had taught between 16 and 25 years, and $15 \%(n=29)$ had taught 26 or more years. Finally, 53\% $(n=103)$ of teachers had been at the school for up to five years, $35 \%(n=68)$ had been at the school for between 6-15 years, $10 \%(n=21)$ for $16-25$ years, and only $1 \%(n=2)$ of teachers had been at the school for 26 or more years.

\section{Procedure}

Participants. After Institutional Review Board approval to conduct the study with teachers and librarians from local schools in the community was received, schools were selected from a list provided by school district administrators. Only schools with full-time librarians were considered for the study. Once schools had been identified, a meeting with the principal of each school took place. This was followed by a formal application to the school district to conduct research at the school. After each district approved the study, principals were again contacted to assist the researcher in scheduling a time for distribution of the instrument. All principals agreed to allow the researcher and research assistants to attend a faculty meeting and to distribute the instrument at that time. Participants received token compensation for their time.

Development of the Instrument. The instrument was constructed to test a proposed model of teacher and librarian collaboration (Montiel-Overall, 2005) with four facets of teacher and librarian collaboration previously mentioned (Coordination, Cooperation, Integrated Instruction, and Integrated Curriculum). The instrument consisted of several sections, which asked participants to rate aspects of teacher and librarians collaboration such as levels of trust, interest, innovation, and time. This paper reports only on a 32-item section designed to measure types of activities reflected in the four facets of the TLC Model. A prototype of the instrument was constructed after an extensive review of the literature, and contained items from a previous study (ibid.). The list of items was reviewed by a panel of expert teachers and librarians.

Content Validity. In order to ensure face and content validity of the instrument, the theoretical framework proposed in the TLC Model was used along with the expert opinion of teacher and librarian panelists from one of the school districts from which participants in the study were employed. Librarian expert panelists who assisted with the development of the instrument were nominated by school district administrators because they were well respected for their ability to work with teachers collaboratively on instruction. Teacher panelists were selected by the librarians. Among the teacher-librarian panelists was a winner of a national award for her collaboration with teachers. Another panelist had helped develop library standards approved by the school board for the school district. The standards required teacher and librarian collaboration for implementation. Teachers included on the panel were 
considered expert teacher and librarian collaborators by the librarian and the school principal. Those recruited for the panels each had over 10 years teaching and/or library experience. In addition to the panelists, a statistician reviewed the instrument during and after its development to ensure clarity of wording.

Review of items by panelists included extensive discussion and revision until final agreement by panelists was reached. Several rounds of reviews occurred. First one panel of four teachers and librarians reviewed the prototype of the survey to change or delete items to the original list and to generate additional items (statements) that would describe collaborative practices between teachers and librarians. A second panel then reviewed the revisions and selected redundant items to eliminate and created the final list of items with four items for each facet of the TLC Model. This was done to ensure adequate representation in each category (Fabrigar et al., 1999).

Field testing. After the panels had reviewed the survey, the instrument was administered to a small group of teachers and librarians $(n=23)$ from a school district in the community where the instrument was later field tested. Participants were recruited by school librarians. The participants signed a consent form according to Institutional Review Board procedures. Each participant received a token compensation for completing the survey and for discussing it with the researcher afterwards. Participants recommended changes in wording for clarity and reorganization of like-items. The survey took approximately 20 minutes and the postsurvey discussion took approximately 25 minutes. High internal consistency was demonstrated on the 38 items in the subsection of teacher and librarian collaboration survey (Coefficient alpha $=0.93$ ).

Refinement of instrument. Further refinement of the TLC-II continued after fieldtesting and redundant items were removed as suggested by participants during field-testing of the instrument. A final revision was made of the instrument and instructions were reworded for clarity to increase reliability of the instrument. The final version of was a pencil and paper self-administered survey, which contained several sections. The first section, reported on in this paper, contained two sets of 16 items answered on a 4-point Likert-type scale. The first set of 16 items was related to the frequency with which practices occurred and were scaled between 1 (never) and 4 (always). Respondents were asked to rate the frequency of practices such as working with teachers to arrange visits to the library for students and jointly planning, teaching, and evaluating students. Using the same set of 16 statements, participants were also asked to rate how important to student learning they thought the practice was. A 4point Likert-type scale ranging from 1 (not at all important) to 4 (always important) to was used for these items.

Missing data. Of the teacher participants, 10 cases were missing data for one or more items. Expectation maximization (EM) was the method used for handling missing data in this study. EM is an iterative procedure involving multiple steps (Expectation and Maximisation) described in Graham et al., (2003). The procedure utilizes partially observed data to determine missing values and is considered preferable to listwise deletion used as the default on the Statistical (SPSS) statistical package used for this study. (For further discussion of missing data on surveys see Montiel-Overall, 2008b.)

\section{Analysis}


Exploratory factor analysis were carried out on teacher responses $(N=194)$ for each of the two sets of 16 questions. Kaiser-Meyer-Olkin (KMO) measure of sampling adequacy was conducted to determine appropriate use of exploratory factor analysis. KMO results was for frequency was .90 and for importance to student learning was .89 indicating correlations between pairs of variables were sufficiently high to proceed with exploratory factor analysis (EFA). Principal axis factoring (with communalities substituted for values of 1.0 in the correlation matrix) was used to extract the factors and oblique (Promax) and orthogonal (Varimax) rotation were performed to rotate to "simple structure" (Thurstone, 1947) for the two sets of variables, Frequency (F1-F16) and Importance to Student Learning (SL1-SL16). Both orthogonal and oblique rotations yielded similar results but because factors were expected to be correlated both theoretically (and were so in practice), the results of the oblique rotation are discussed here. Descriptive statistics (Means and standard deviations) for both scales (Frequency and Importance to Student Learning) are provided on Table 1.

Table 1. Means and Standard Deviations for Teacher and Librarian Collaborative Practices MostFrequently Performed (F1-F16) and Most Important to Student Leaming (SL1-SL16) as Perceived by Teachers $(N=194)$

\begin{tabular}{|c|c|c|c|}
\hline Item & & Mean & $\mathrm{SD}$ \\
\hline$\overline{F 1}$ & T/L work to arrange times for library use & 2.36 & .79 \\
\hline F2 & $T / L$ spend time to organize instructional activities in the library & 1.97 & .71 \\
\hline F3 & $T / L$ work to coordinate schedules & 2.30 & .87 \\
\hline F4 & T schedules time for $\mathrm{L}$ to talk to students about a particular book & 1.82 & .79 \\
\hline F5 8 & $\mathrm{~T} / \mathrm{L}$ discuss library materials for teaching & 2.30 & .81 \\
\hline F6 & $\mathrm{T} / \mathrm{L}$ discuss what students will do when they go to the library & 2.35 & .77 \\
\hline $\mathrm{F} 7^{8}$ & T asks I for resources for instruction & 2.67 & .67 \\
\hline F8 8 & $\mathrm{~T} / \mathrm{L}$ divide responsibilities when working together & 2.18 & .78 \\
\hline F9 & $\mathrm{T} / \mathrm{L}$ jointly plan objectives for lessons & 1.65 & .68 \\
\hline F10 $10^{8}$ & $T / L$ implement less ons together & 1.75 & .73 \\
\hline F11 & $\mathrm{T} / \mathrm{L}$ integrate library curriculum into teaching & 2.28 & .86 \\
\hline F12 & $\mathrm{T} / \mathrm{L}$ jointly evaluate students' progress & 1.66 & .77 \\
\hline F138 & $\mathrm{T} / \mathrm{L}$ jointly develop objectives in school district & 2.01 & .81 \\
\hline F14 & $\mathrm{T} / \mathrm{L}$ jointly plan les s ons in school district & 1.93 & .79 \\
\hline F15 & $\mathrm{T} / \mathrm{L}$ jointly participate in curriculumplanning in $5 \mathrm{chool} \mathrm{district}$ & 2.09 & .87 \\
\hline F16 & $\mathrm{T} / \mathrm{L}$ jointly teach together in 5 chool district & 2.04 & .84 \\
\hline SL 1 & $\mathrm{~T} / \mathrm{L}$ work to arrange times for library use & 3.13 & .77 \\
\hline SL2 & $T / L$ spend time to organize instructional activities in the library & 2.97 & .76 \\
\hline SL 3 & $T / L$ work to coordinate schedules & 3.17 & .77 \\
\hline SL4 & T schedules time for $\mathrm{L}$ to talk to students about a particular book & 2.78 & .83 \\
\hline SL 5* & $\mathrm{T} / \mathrm{L}$ discuss library materials for teaching & 3.11 & .76 \\
\hline SL6 & $\mathrm{T} / \mathrm{L}$ discuss what students will do when they go to the library & 3.07 & .72 \\
\hline $\mathrm{SL} 7^{\circ}$ & T asks I for res ources for instruction & 3.34 & .67 \\
\hline SL $8^{8}$ & $\mathrm{~T} / \mathrm{L}$ divide responsibilities when working to gether & 3.04 & .80 \\
\hline SL9 & $\mathrm{T} / \mathrm{L}$ jointly plan objectives for les sons & 2.68 & .89 \\
\hline SL $10^{*}$ & $\mathrm{~T} / \mathrm{L}$ implement les s ons together & 2.72 & .84 \\
\hline SL 11 & $T / L$ integrate library curriculum into teaching & 3.09 & .74 \\
\hline SL 12 & $T / L$ jointly evaluate students' progress & 2.50 & .91 \\
\hline SL 13* & $\mathrm{T} / \mathrm{L}$ jointly develop objectives in school district & 2.80 & .85 \\
\hline SL 14 & $\mathrm{~T} / \mathrm{L}$ jointly plan les s ons in school district & 2.70 & .86 \\
\hline SL 15 & $\mathrm{~T} / \mathrm{L}$ jointly participate in curriculumplanning in school district & 2.86 & .81 \\
\hline SL 16 & $T / L$ jointly teach together in school district & 2.81 & .85 \\
\hline
\end{tabular}

Note: Means are arranged from highest to lowest for each scale, Frequency and Importance to Student Learning. Four point scales were used for both Frequency and Importance to Student Learning.

*Items ranked in the same position on both scales.

\section{Results}


Extraction of Factors. Initial analysis of unrotated factors using Principal Axis Factoring was carried out yielding four factors. PAF extraction indicated that factors were highly correlated, as anticipated. The criterion of eigenvalue $>1$ (Kaiser, 1960) and the scree test (Cattell, 1966) were both used to determine the appropriateness of the four factor model (Fabrigar et al., 1999). A strong central factor representing approximately $45 \%$ of the total variability in the variables was present. The first factor accounted for over $45 \%$ of the variance with the next three factors representing $13.5 \%, 7.3 \%$, and $6.6 \%$ of the total variability (the four eigenvalues were approximately $7.22,2.16,1.17$, and 1.06; the total variability for 16 variables was 16.0 ).

Communalities among all measured factors for Frequency items (F1-F16) were examined to determine the percent of variance in a given variable for all factors extracted. Communalities among Frequency items (F1-16) were moderate to high ranging from .42 to .80 (Table 2). Communalities are considered high when they are $>.6$ (MacCullum et al., 1999). The unrotated loadings showed the presence of a strong central factor, with loadings ranging from 59 to .76 , which is a common result when factors are highly correlated. Accordingly, rotation results were examined for interpretability.

Rotation of Factor Loading Matrices. PAF with orthogonal (Varimax) and oblique (Promax) rotations were carried out for further interpretation. Since four constructs were postulated to underlie the data, a four factor model was requested in the rotation. Results from both methods were similar.

\begin{tabular}{|c|c|c|c|c|c|}
\hline \multirow[t]{2}{*}{ Item } & \multirow[t]{2}{*}{ Communality } & \multicolumn{4}{|c|}{ Factor Loadings } \\
\hline & & $\begin{array}{l}\text { Factor 1: } \\
\text { Integrated Instr. }\end{array}$ & $\begin{array}{l}\text { Factor 2: } \\
\text { Integrated Cur. }\end{array}$ & $\begin{array}{l}\text { Factor 3: } \\
\text { Coordination }\end{array}$ & $\begin{array}{l}\text { Factor 4: } \\
\text { Cooperative Role }\end{array}$ \\
\hline F10 & 0.76 & 0.95 & $\cdots$ & $\ldots$ & $\ldots$ \\
\hline F9 & 0.70 & 0.88 & $\ldots$ & $\ldots$ & $\ldots$ \\
\hline F2 & 0.59 & 0.62 & $\ldots$ & $\ldots$ & $\ldots$ \\
\hline F11 & 0.43 & 0.53 & $\ldots$ & $\ldots$ & $\ldots$ \\
\hline F12 & 0.42 & 0.61 & $\ldots$ & $\ldots$ & $\cdots$ \\
\hline F4 & 0.49 & 0.50 & $\cdots$ & $\cdots$ & $\cdots$ \\
\hline F13 & 0.79 & $\ldots$ & 0.86 & $\ldots$ & $\ldots$ \\
\hline F16 & 0.77 & $\ldots$ & 0.84 & $\ldots$ & $\ldots$ \\
\hline F14 & 0.70 & $\ldots$ & 0.84 & $\ldots$ & $\ldots$ \\
\hline F15 & 0.77 & $\cdots$ & 0.87 & $\ldots$ & $\ldots$ \\
\hline $\mathrm{F} 1$ & 0.75 & $\cdots$ & $\cdots$ & 0.89 & $\ldots$ \\
\hline F3 & 0.80 & $\ldots$ & $\ldots$ & 0.90 & $\ldots$ \\
\hline F7 & 0.78 & $\ldots$ & $\ldots$ & $\ldots$ & 0.96 \\
\hline F5 & 0.59 & $\ldots$ & $\ldots$ & $\ldots$ & 0.65 \\
\hline F8 & 0.55 & $\ldots$ & $\ldots$ & $\ldots$ & 0.51 \\
\hline
\end{tabular}

Oblique (Promax) rotation may be more difficult to interpret because items may load on more than one factor. Three sets of "loadings" are available in oblique rotation. The pattern matrix provided the most interpretable results and was used for interpretation as recommended by Tabachnick and Fidell (1996). However, the structure matrix and content of items were also used in interpreting results. Table 3 presents the factor correlation matrix, which indicates the relative independence of the various constructs. Factor 1 was highly correlated with all variables. However, the correlations between Factor 2 and Factors 3 and 4 
were relatively low. The pattern and structure matrices provided additional information distinguishing variables (Table 4). $\mathrm{A} \pm .50$ threshold was loosely used to identify items that characterized the factor (Ibid.).

\begin{tabular}{llrrr} 
Table 3 Factor Correlation Matrix for Frequency & \\
\hline Factor & 1 & 2 & 3 & 4 \\
\hline 1. Integrated Instruction & 1.000 & .525 & .584 & .613 \\
2. Integrated Curriculum & .525 & 1.000 & .298 & .378 \\
3. Coordination & .584 & .298 & 1.000 & .562 \\
4. Traditional Cooperative T/L Role & .613 & .378 & .562 & 1.000
\end{tabular}

Factor 1 was moderately to highly correlated with F9, F10, F11, F12 (.53-.95) and to a lesser extent to F2 and F4 (.62 and .50 respectively) in the pattern matrix. This was similar to the loadings on the structure matrix. However on the structure matrix, items were less well defined with cross-loadings for six items (F2, F3, F4, F5, F6, and F8). Content of items was used for further interpretation of this factor. Since the six items in the pattern matrix were associated with collaborative practices in which teachers and librarians integrated course content and library curriculum in their instruction, the label assigned to this factor was Course Integrated Instruction.

Factor 2 was defined by four closely related items, F13-F16 (.84-.87), with high factor loadings and substantially smaller correlations for other variables on both the pattern and structure matrices. Items in Factor 2 were associated with joint planning and teaching across the school district. Examples of statements for this factor include "Teachers and librarians in my school district jointly develop objectives for instruction" and "Teachers and librarians in my school district teach together (e.g. plan and implement lessons that integrate the academic curriculum-math, science, social studies- with library instruction)." Since as all items referred to integrated instruction across the school district, Factor 2 was labelled Integrated Curriculum.

Factor 3 was defined by two items on the pattern matrix, F1 and F3 (.89 and .90 respectively) with the remaining loading having low or negative values. On the structure matrix, F1, F2, F3, F4, and F6 (.58 to .89) loaded moderately to highly with F6 loading on three factors $(1,3$, and 4$)$ indicating shared variance with other factors. An examination of the content of these items revealed practices attributed to management efforts (e.g., arrange time, schedule time, coordinate schedules). Examples of statements for these items included "Working with the librarian to coordinate schedules so that students can use the library," "Working with the librarian to arrange time periods for students to use the library," and "Scheduling time for the librarian to talk to students about a book." Factor 3 generally corresponded to a low level of collaboration on the TLC Model (Facet A: Coordination). Accordingly, Factor 3 was labelled Coordination of Activities.

Factor 4 was defined by three items F5, F7, and F8 (.65, .96, and .51 respectively) on the pattern matrix, and by four items on the structure matrix, F5, F6, F8, and F9 $(.76, .60, .68$, and .50). While no crossloads were observed in the pattern matrix, four occurred in the structure matrix (F5, F6, F8, and F9). F6 loaded on multiple factors in the structure matrix and did not load on the pattern matrix. This item apparently had elements that pertained to multiple factors rather than "simple structure" (Thurstone, 1935). An examination of the content of other variables in this factor was used to determine the most appropriate structure since there is no single correct solution. Factor 4 was labelled Traditional Cooperative Role since it contained items that implied cooperative endeavors between teacher and librarian in which the librarian carried out traditional responsibilities of helping teachers find resources for teaching and dividing responsibilities. Examples of statements in Factor 4 include "asking the librarian for library resources to use in instruction," "spending time with the librarian to 
discuss library materials (e.g. books, websites, references) needed for teaching," and "dividing responsibilities when jointly working (e.g. librarian gathers resources for a lesson that you [the teacher] will teach)."

\begin{tabular}{|c|c|c|}
\hline Item Stem & Pattern & Structure \\
\hline $\begin{array}{l}\text { Factor } 1 \text { Course Integrated Instruction } a=0.87 \\
\text { F10 T/L implementing lessons } \\
\text { F9 T/L planning objectives for lessons } \\
\text { F2 T/L spending time to organize instructional activities } \\
\text { F11 T/L integrate library curriculum into teaching } \\
\text { F12 T/L evaluating students 'progress } \\
\text { F4 T/L schedule time for librarian to talk to students } \\
\text { about a book }\end{array}$ & $\begin{array}{l}.95 \\
.88 \\
.62 \\
.53 \\
.61 \\
.50\end{array}$ & $\begin{array}{l}.86 \\
.84 \\
.74 \\
.65 \\
.62 \\
.65\end{array}$ \\
\hline $\begin{array}{l}\text { Factor } 2 \text { Integrated Curriculum } \quad \alpha=0.93 \\
\text { F13 T/L jointly develop objectives in school district } \\
\text { F16 T/L teach together in school district } \\
\text { F14 T/L jointly plan lessons in school district } \\
\text { F15 T/L jointly participate in curriculum planning }\end{array}$ & $\begin{array}{l}.86 \\
.84 \\
.84 \\
.87\end{array}$ & $\begin{array}{l}.89 \\
.84 \\
.88 \\
.88\end{array}$ \\
\hline $\begin{array}{l}\text { Factor } 3 \text { Coordination of Activities } a=0.87 \\
\text { F1 T/L arrange times for library use } \\
\text { F3 T/L coordinate schedules }\end{array}$ & $\begin{array}{l}.89 \\
.90\end{array}$ & $\begin{array}{l}.86 \\
.89\end{array}$ \\
\hline $\begin{array}{l}\text { Factor } 4 \text { Traditional Cooperative T/L Roles } \alpha=0.81 \\
\text { F7 T asks librarian for library resources for instruction } \\
\text { F5 T/L discuss library materials needed for teaching } \\
\text { F8 T/L divide responsibilities when working together }\end{array}$ & $\begin{array}{l}.96 \\
.65 \\
.51\end{array}$ & $\begin{array}{l}.87 \\
.80 \\
.68\end{array}$ \\
\hline
\end{tabular}

\section{Importance to student learning}

Extraction of Factors. Initial analysis of unrotated factors using Principal Axis Factoring was carried out yielding three factors. The criterion of eigenvalue $>1$ (Kaiser, 1960) and the scree test (Cattell, 1966) were both used to determine the appropriateness of the three factor model (Fabrigar et al., 1999). A four factor model was supported by the scree test (Cattell, 1966) with a slight elbow after the fifth factor. The last factor fell just under the eigenvalue $>1$ rule (Kaiser, 1960) but was interpretable so it was retained. PAF extraction indicated that factors were highly correlated, as anticipated. A strong central factor representing approximately $48 \%$ of the total variability in the variables was present. The first factor accounted for over $48 \%$ of the variance with the next three factors representing $12.7 \%$, $6.43 \%$, and $5.71 \%$ of the total variability (the four eigenvalues were approximately 7.75 , $2.04,1.03$, and .91 ; the total variability for 16 variables was 16.0 ).

Communalities among all measured factors for Importance to Student Learning items (SL1-SL16) were examined to determine the percent of variance in a given variable for all factors extracted. Communalities among Importance to Student Learning items (SL1-SL16) were moderate to high ranging from .49 to .84 (Table 5). Communalities are considered high when they are >.6 (MacCullum et al., 1999). As with the Frequency variables, all items had high loadings on the first unrotated factor with loadings ranging from .54 to .78 , which is a common result when factors are highly correlated. Accordingly, rotation results were examined for interpretability. 
Rotation of Factor Loading Matrices. Oblique (Promax) rotation was again selected because factors were expected to be correlated. As with the Frequency variables, four factors were selected for rotation and a $+/-.50$ threshold was used to identify items that defined each factor (Tabachnick \& Lidell, 1996). Three sets of loadings available in oblique rotation were examined in interpreting the data.

\begin{tabular}{|c|c|c|c|c|c|}
\hline \multirow[t]{2}{*}{ Item } & \multirow[t]{2}{*}{ Communality } & \multicolumn{4}{|c|}{ Factor Loadings } \\
\hline & & $\begin{array}{l}\text { Factor 1: } \\
\text { Integrated Cur. }\end{array}$ & $\begin{array}{l}\text { Factor 2: } \\
\text { Integrated Instr. }\end{array}$ & $\begin{array}{l}\text { Factor 3: } \\
\text { Coordination }\end{array}$ & $\begin{array}{l}\text { Factor 4: } \\
\text { Cooperative Role }\end{array}$ \\
\hline$\overline{\text { SL15 }}$ & 0.84 & 0.94 & $\ldots$ & $\ldots$ & $\ldots$ \\
\hline SL13 & 0.82 & 0.89 & $\ldots$ & $\ldots$ & $\ldots$ \\
\hline SL14 & 0.81 & 0.83 & $\ldots$ & $\ldots$ & $\ldots$ \\
\hline SL16 & 0.66 & 0.76 & $\ldots$ & $\ldots$ & $\ldots$ \\
\hline SL10 & 0.78 & $\ldots$ & 0.95 & $\ldots$ & $\ldots$ \\
\hline SL9 & 0.76 & $\ldots$ & 0.94 & $\ldots$ & $\ldots$ \\
\hline SL12 & 0.51 & $\ldots$ & 0.63 & $\ldots$ & $\ldots$ \\
\hline SL11 & 0.49 & $\ldots$ & 0.45 & $\ldots$ & $\ldots$ \\
\hline $\mathrm{SL} 3$ & 0.79 & $\ldots$ & $\ldots$ & 1.02 & $\ldots$ \\
\hline SL1 & 0.64 & $\ldots$ & $\ldots$ & 0.76 & $\ldots$ \\
\hline SL7 7 & 0.72 & $\ldots$ & $\ldots$ & $\ldots$ & 0.93 \\
\hline SL5 & 0.56 & $\ldots$ & $\ldots$ & $\ldots$ & 0.74 \\
\hline SL8 & 0.61 & $\ldots$ & $\ldots$ & $\ldots$ & 0.62 \\
\hline
\end{tabular}

Substantial intercorrelations among the factors indicate that the constructs, while identifying some unique variability were highly related to each other. Table 6 contains the correlation matrix for the Importance to Student Learning scale. Correlations were quite high.

Table 6 Factor Correlation Matrix for Importance to Student Learning

\begin{tabular}{lcrrr}
\hline Factor & 1 & 2 & 3 & \multicolumn{1}{c}{4} \\
\hline 1. Integrated Instruction & & & & \\
2. Integrated Curriculum & 1.000 & .668 & .403 & .431 \\
3. Coordination & .668 & 1.000 & .619 & .601 \\
4. Traditional Cooperative T/L Role & .403 & .619 & 1.000 & .681 \\
& .431 & .601 & .681 & 1.000
\end{tabular}

Factor 1 was defined by four items, SL13-SL16, with loadings from .76-.94 in the pattern matrix and slightly higher loading in the structure matrix (.80-.91) (see Table 6). Examination of content indicated these four items were strongly related to collaborative practices across the school district, and were thus assigned the label, Integrated Curriculum. Items in this factor included "teachers and librarian in my school district jointly participate in curriculum planning," and "teachers and librarian in my school district jointly develop objectives for instruction." 


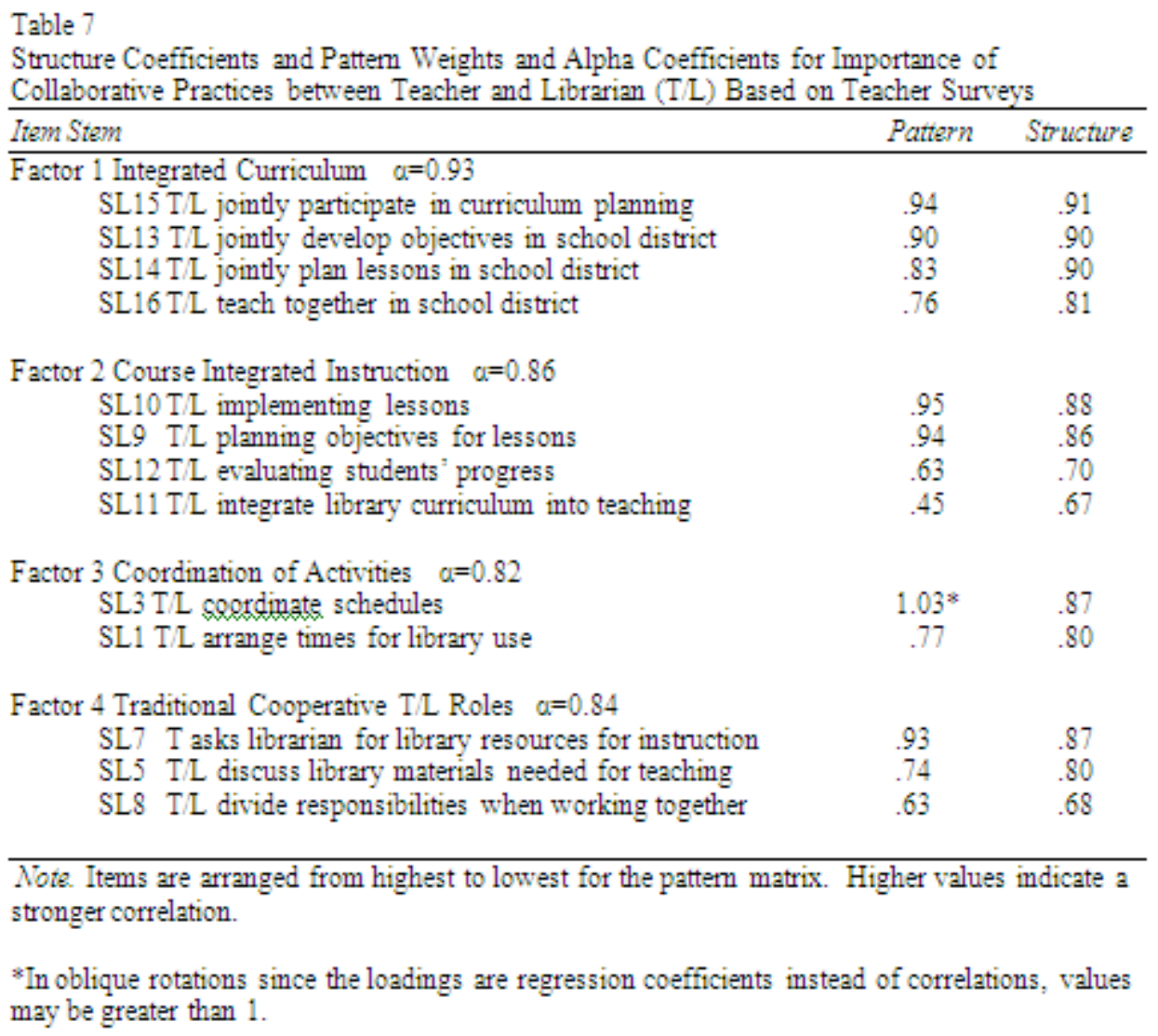

Factor 2 correlated moderately to highly with four items SL9-SL12 on the pattern matrix with loadings from .45-.95, and substantially smaller correlations for other variables. On the structure matrix, the SL9-SL12 items displayed moderate to high correlations (.67.88 ). The association among these items was joint planning and implementation of library lessons, and classroom instruction reflected in statements such as "planning objectives for lessons with the librarian," "implementing lessons with the librarian," and "integrating the library curriculum into my teaching." (These same items loaded highly on Factor 1 of the Frequency subscale along with three additional items, F2, F4, and F6). Factor 2 of the Importance to Student Learning subscale was labelled Course Integrated Instruction since the items were associated with collaborative practices in which classroom teachers and librarians integrate library curriculum and subject content.

Factor 3 was most highly related to SL1 and SL3 (.77 and 1.03 respectively) on the pattern matrix. These items also loaded highly on the structure matrix (.79-.84) along with SL2 and SL4, which loaded moderately on the structure matrix (.65 and .66 respectively) and cross-loaded with Factors 2 and 3. To reflect the content of items in this factor, the label assigned to Factor 3 was Coordination of Activities associated with practices of arranging schedules and organizing time and planning instructional activities.

Factor 4 was defined by three items, SL7, SL5, and SL8 $(.93,74$, and .63 respectively) on the pattern matrix, and by an additional item, SL6 (.57), on the structure matrix, which cross-loaded on two other factors. The main implication of these items was librarians working with teachers to determine appropriate resources for instruction and to gather resources. As with the Frequency variables, these items represent traditional roles in which librarians worked cooperatively helping teachers. For example, statements such as "spend time with the librarian to discuss library materials (e.g. books, websites, references) needed for teaching," "asking the librarian for library resources to use in instruction," and "dividing responsibilities when jointly working (e.g. librarian gathers resources for a lesson that you will teach" identify practices that have traditionally been carried out by librarians. 
These practices represent a level of collaboration labelled Cooperation in the TLC Model. The label assigned to this factor corresponded to the label applied to Factor 4 of the Frequency subscale, Traditional Cooperative T/L Roles. This label was selected to provide greater clarity in understanding the content of the items which made up the factor. Table 6 contains structure coefficients and pattern weights. While no items with high loadings appeared in multiple factors in the pattern matrix, three occurred in the structure matrix $(\mathrm{F} 2$, F4, F6).

\section{Internal Consistency}

Internal consistency of the TLC II Survey was determined using Cronbach's alpha reliability coefficients in SPSS 15.0. Results are shown in Table 8. The overall scale alpha for all 16 items for Frequency was 0.92 . The overall scale alpha for the 16 items in Importance to Student Learning was 0.93.

Table 8 Alpha Reliability Coefficients

Frequency Importance to Student Learning

$\begin{array}{lcc}\text { Overall alpha } & 0.92 & 0.93 \\ \text { Course Integrated Instruction } & 0.87 & 0.86 \\ \text { Integrated Curriculum } & 0.93 & 0.93 \\ \text { Coordination } & 0.87 & 0.82 \\ \text { Traditional Cooperative T/L Role } & 0.81 & 0.84\end{array}$

\section{Discussion}

This study explored teachers' perceptions on teacher and librarian collaboration on an instrument designed to reflect various collaborative practices between teachers and librarians (TLC-II Survey). Four factors emerged from the factor analysis, which resembled the facets postulated in the TLC Model. The TLC-II Survey will require further preparation before widespread distribution, however. For example, the Coordination of Activities scale will require additional items for stability. The other factors may also benefit from additional items and rewording of items to improve internal consistency. However, since the self-report instrument typically takes only about 15 minute to complete (a positive feature given the limited time teachers and librarians have outside the classroom), care will be needed in revising the instrument to ensure that parsimony and brevity are maintained.

Several important limitations should be noted. Only teachers' responses were reported, and while it is important to examine teachers' perceptions about teacher and librarian collaboration, librarian responses are equally valuable. Future studies will be needed to examine a sufficient number of librarians to compare teacher responses to librarian responses on frequency and importance of teacher and librarian collaboration. A second important limitation is that the instrument may not be representative outside the community in which it was used, and caution should be used in interpreting results to broader populations outside the southwestern or in rural communities.

The TLC-II Survey may be a valuable tool in assessing the types of collaborative endeavors that occur between teachers and librarians, and may help determine types of teacher and librarian collaboration that improve student learning. 


\section{References}

American Association of School Librarians and Association for Educational Communications and Technology (AASL \& AECT). (1998). Information power: Building partnerships for learning. Chicago: American Library Association.

Abilock, D. (2002). Ten attributes of collaborative leaders. Knowledge Quest, 31(2), 8-10.

Bush, G. (1998). Be true to our school. Knowledge Quest 26(3), 28-31.

Buzzeo, T. (2003). Collaborating to meet standards: Teacher/librarian partnerships K-12. Knowledge Quest, 32(1), 29-30.

Callison, D. (1997). Expanding collaboration for literacy promotion in public and school libraries. Journal of Youth Services, 11, 37-48.

Costello, A. B. \& Osborne, J. W. (2005). Best practices in Exploratory Factor Analysis: Recommendations for getting the most from your analysis. Practical Assessment Research \& Evaluation, 10(7), 1-9.

Cattell, R. B. (1966). The scree test for the number of factors. Multivariate Behavioral Research, 1, 245-276.

Donninger, G. L., Enders, C. \& Burnett, K. F. (2005). Validity for eating attitudes test scores in a sample of female college athletes. Measure in Physical Education and Exercise Science, 9(1), 35-49.

Fabrigar, L. R., Wegener, D. T., MacCallum, R. C., \& Strahan, E. J. (1999). Evaluating the use of exploratory factor analysis in psychological research. Psychological Methods, 4(3), 272-299.

Graham, J. W., Cumsille, P. E., \& Elek-Fisk, E. (2003). Methods for handling missing data. In J. A. Schinka \& W. F. Velicer (Eds.). Research Methods in Psychology (pp. 87_114). Volume 2 of Handbook of Psychology (I. B. Weiner, Editor-in-Chief). New York: John Wiley \& Sons.

Haycock, K. (2003). Collaboration: Because student achievement is the bottom line. Knowledge Quest, 32(1), 54.

Jinkins, B. (2001). Collaboration: A road map to success. Knowledge Quest, 29(2), 26-27.

Kaiser, H.F. (1960). The application of electronic computers to factor analysis. Educational and Psychological Measurement, 20, 141-151.

Lance, K. C., Wellburn, L., \& Hamilton-Pennell, C. (1993). Impact of school library media centers on academic achievement. Castle Rock, CO: Hi Willow.

Lance, K. C. (1994). The impact of school library media centers on academic achievement. School Library Media Quarterly, 22(33), 167-170, 172.

Lance, K. C., Hamilton-Pennell, C., \& Rodney, M. J. (1999). (with Peterson, L., \& Sitter, C.). Information powered: The school librarian as an agent of academic achievement in Alaska. Executive Summary. Retrieved April 2, 2008, from http://www.library.state.ak.us/pdf/anc/infoemxs.pdf

Lance, K. C., Rodney, M. J., \& Hamilton-Pennell, C. (2000). How school library media specialists help kids achieve standards: The second Colorado study. San Jose, CA: HiWillow.

Lance, K. C. (2001). Proof of the power: Quality library media programs affect academic achievement. Retrieved April 1, 2008. http://www.infotoday.com/MMSchools/sep01/lance.htm 
Lance, K. C., Rodney, M. J. \& Hamilton-Pennell, C. (2001). Good schools have school library media specialists: Oregon SLMSs collaborate to improve academic achievement. Salem, OR: Oregon Educational Media Assoc.

Lance, K. C. (2002). What research tells us about the importance of school libraries. White House Conference on School Libraries. Institute of Museum and Library Services. Retrieved June 10, 2007, from http://www.imls.gov/news/events/whitehouse 2.shtm\#kcl

Lance, K. C., Rodney, M. J., \& Hamilton-Pennell, C. (2002). How School Libraries Improve Outcomes for Children: The New Mexico Study.

Lance, K. C., \& Russell, B. (2004). Scientifically based research on school libraries and academic achievement: What is it? How much do we have? How can we do it better? Knowledge Quest, 32(5), 13-17.

Lance, K. C., Rodney, M. J., \& Hamilton-Pennell, C. (2005). Powerful libraries make powerful learners: The Illinois study. Canton, IL: Illinois School Library Media Association Retrieved April 2, 2008, from http://www.islma.org/pdf/ILStudy2.pdf

Loertscher, D. V. (1982). Second revolution: A taxonomy for the 1980s. Wilson Library Bulletin, 56, 412-21.

Loertscher, D. V. (1988). Taxonomies of the school library media program. Englewood CO: Libraries Unlimited

Loertscher, D. V. (2000). Taxonomies of the school library media program. 2nd ed. San José, Calif.: Hi Willow.

Milbury, P. (2005). Collaboration: Ten important reasons to take it seriously. Knowledge Quest, 33(5), 30-32.

Montiel-Overall, P. (2005). Toward a theory of collaboration for teachers and librarians. School Library Media Research, 8. Retrieved April 2, 2008, from http://www.ala.org/ala/aasl/aaslpubsandjournals/slmrb/slmrcontents/volume82005/theory.cfm

Montiel-Overall, P. (2006). Teacher and teacher-librarian collaboration: Moving toward integration. Teacher Librarian, 34(2), 28-33.

Montiel-Overall, P. (2007). Research on teacher and librarian collaboration: An examination of underlying structures of models. Library and Information Science Research, 29(2), 277-292.

Montiel-Overall, P. (2008a). Teacher and librarian collaboration: A qualitative study. Library and Information Science Research, 30(2) in press.

Montiel-Overall, P. (2008b). Implications of missing data on surveys. Canadian Journal of Library and Information Science, 30(1).

Rodney, M. J., Lance, K. C., \& Hamilton-Pennell, C. (2002). Make the connection: Quality school library media programs impact academic achievement in Iowa.Bettendorf, IA: Mississippi Bend Area Education Agency Retrieved April 2, 2008, from

http://www.aea9.k12.ia.us/documents/Media_Services_Statewide_Library_Study.pdf

Rodney, M. J., Lance, K. C., \& Hamilton-Pennell, C. (2003). The impact of Michigan school librarians on academic achievement: Kids who libraries succeed. Retrieved April 2, 2008, from http://www.michigan.gov/documents/hal $1 \mathrm{~m}$ schllibstudy03 $76626 \quad 7 . \mathrm{pdf}$

Tabachnick B. G. \& Fidell, L.S. (1996). Using Multivariate Statistics (3 ${ }^{\text {rd }}$ Ed.), pp. 635-707. New York: Harper Collins.

Thurstone, L. L. (1947). Multiple-factor Analysis: A Development and Expansion of the Vectors of the Mind. Chicago: University of Chicago Press. 


\section{Biographical Notes}

Patricia is an assistant professor at the University of Arizona School of Information Resources and Library Science. She recently received a $\$ 300,000$ grant from IMLS to conduct research on "The Effect of Teacher and Librarian Collaboration on Science Information Literacy of Latino Students." Patricia received a doctorate from Stanford University.

\section{Statement of Originality}

This statement certifies that the paper above is based upon original research undertaken by the author and that the paper was conceived and written by the author(s) alone and has not been published elsewhere. All information and ideas from others is referenced. 